Bangladesh J. Zool. 48(1): 211-212, 2020

- Scientific note

ISSN: 0304-9027 (print)

2408-8455 (online)

\title{
POSSIBLE ROLE OF MIGRATORY BIRDS ON CORONA VIRUSES TRANSMISSION: SCIENTIFIC AND SOCIAL IMPLICATIONS
}

\author{
Murshida Begum* \\ Department of Zoology, University of Dhaka, Dhaka-1000, Bangladesh
}

Involvements with corona viruses are not new for the bird population but the present COVID 19 situation is major thinks to worry about human being. Corona viruses (CoVs) are a large group of protein coated single stranded RNA genome, causative agents of significant diseases resulting in generous impact on human and animal health. Severe acute respiratory syndrome corona virus (SARS-CoV) and Middle East respiratory syndrome corona virus (MERS-CoV) equally have caused marked distress on human health, including a number of deaths, and have had noteworthy socioeconomic impacts on the countries in which peoples were infected. CoVs sheltered by avian species were classified into two types of genera named gamma and delta corona viruses. Among the gamma-CoVs the main representative is avian corona virus, a taxonomic name includes the highly contagious infectious bronchitis viruses (IBVs) in chickens. Similar viruses also infect other domestic birds such as turkeys, guinea fowls, or quails. Additionally, IBVs have been detected in healthy wild birds, indicating that they may act as the vector between domestic and free-living birds (Miłek and Blicharz-Domańska 2018). Turkey corona virus infections have substantial impacts on animal health and cause considerable economic costs to producer as well (Chamings 2018).

In China corona viruses have been isolated from peafowl (Pavo sp.), guinea fowl (Numida sp.), partridge (Alectoris sp.) and also from a nongallinaceous bird, the teal (Anas) as well as geese, pigeons, ducks and psittacines (Cavanagh 2005). The number of avian species in which corona viruses have been detected has doubled in the past couple of years. In Hong Kong ten species of migratory birds were tested positive for corona viruses [viz. Common teal (Anas crecca), Northern shoveler (Spatula clypeata), Eurasian wigeon (Mareca penelope), Northern pintail (Anas acuta), Tufted duck (Aythya

*Author for Correspondence: murshida.begum@du.ac.bd; murshida1972@yahoo.com

(C)2020 Zoological Society of Bangladesh DOI: https://doi.org/10.3329/bjz.v48i1.47890 
fuligula), American wigeon (Mareca americana), Gray heron (Ardea cinerea), Black-crowned Night heron (Nycticorax nycticorax), Great cormorant (Phalacrocorax carbo), Black-faced spoonbill (Platalea minor)] where as in Cambodia only three species were tested positive [viz. Pond heron (Ardeo labacchus/A. speciosa), Lesser whistling duck (Dendrocygna javanica), Ruddybreasted crake (Zapornia fusca) (Chu et al. 2011).

Besides the possibilities of transmission corona viruses to human and other animal body through migratory birds, present COVID-19 season has a positive thing for the bird populations. However, during this COVID-19 danger period humans were enforced to stay inside their houses and as a result nature is reviving. Two major contributors to this reinforcement were found such as, lowering of pollution level and limited human interference. Migratory birds could fly freely without human interference.

In line with these processes migratory birds on their way back to Siberia are foraging in Europe, India and Pakistan (Latif 2020). During this COVID 19 season the people of industrialized Dhaka also have heard the sounds of singing of migratory birds. Almighty didn't create this earth not only for human being, but the other animal diversity also holds equal rights as like as ourselves. They also need safe living environments as occur the COVID 19 season 2020.

\section{LITERATURE CITED}

CAVANAGH, D. 2005. Coronaviruses in poultry and other birds: Review. Avian pathology. 34(6): $439-448$.

CHAMingS, A., NELSON, T. M., VIBIN, J., WILlE, M., KLAASSEN, M. and ALEXANDERSEN, S. 2018.Detection and characterisation of coronaviruses in migratory and non-migratory Australian wild birds. Nature Scientific Reports. 8 (5980): 1-10.

CHU, D. K.W., LEUNG, C. Y. H., GILBERT, M., JOYNER, P. H., ERICA, M. N., TSEMAY, M., TSE, Y. G., JOSEPH, S. M., PEIRIS and POON, L. L.M.2011.Journal of Virology.85(3): 12815-12820.

LATIF, A. 2020. COVID-19 shutdown a boon for migratory birds in Pakistan: While hunters, bird catchers remain indoors, migratory birds on their way back to Siberia are making hay in Pakistan. Asia-Pacific Latest on Coronavirus outbreak, 5th May Issue.

MIŁEK, J. and BLICHARZ-DOMAŃSKA, K. 2018. Coronaviruses in Avian Species - Review with Focus on Epidemiology and Diagnosis in Wild Birds. Journal of Veterinary Research. 62(3): 249-255.

(Manuscript received on 12 February, 2020 revised on 10 March, 2020) 